Dr BORČE ILIEVSKI, vanredni profesor

Filozofski fakultet Univerziteta „Sv. Kirilo i Metodije“

Skopje, Bulevar Goce Delčeva 9A, Republika Makedonija

borce@fzf.ukim.edu.mk

pregledni rad

UDK: 314.117-054.57(=512.161)(497.11-13-89)"192/193"

primljeno: 22. april 2017.

$314.15(=512.161)(497.1) " 192 / 193 "$

prihvaćeno: 11. oktobar 2017.

323.15(=512.161)(497.11-13-89)"192/193"

DOI: 10.29362/IST20VEKA.2018.1.ILI.35-54

\title{
TURCI U KRALJEVINI SHS/JUGOSLAVIJI DEMOGRAFSKA ANALIZA NA OSNOVU POPISA STANOVNIŠTVA 1921. I 1931.
}

APSTRAKT: Na osnovu objavljenih statističkih materijala popisa u Kraljevini SHS/Jugoslaviji iz 1921. i 1931. godine, u članku se daje demografska analiza turske manjine u prvoj jugoslovenskoj državi. Statistički i popisni materijali se upoređuju sa većim brojem istoriografskih, etnografskih i antropogeografskih studija, koje ponekad daju sasvim različitu sliku o brojnosti i strukturi turskog stanovništva, odnosno o popisanom stanovništvu koje koristi turski jezik (prema tadašnjoj statističkoj metodologiji). U radu se posmatraju i migraciona kretanja, odnosno iseljavanje Turaka u međuratnom periodu na osnovu većeg broja demografskih pokazatelja.

KLJUČNE REČI: Turci, Kraljevina Jugoslavija, migracije, demografske promene, popis stanovništva

Među novim državama koje se pojavljuju na političkoj karti Evrope po svršetku Prvog svetskog rata, stanovništvo Kraljevstva Srba, Hrvata i Slovenaca / Jugoslavije u pogledu verske i nacionalne strukture predstavlja najsloženiju zajednicu zbog heterogenog sastava populacije. ${ }^{1}$ Pored konstitutivnih Srba, Hrvata i Slovenaca, te nepriznatih južnoslovenskih naroda, u državi su živele brojne nejužnoslovenske manjine, uglavnom različite u pogledu kulture, tradicije $i$ istorijskog razvitka. Jednu od manjina koja će po stvaranju države decembra 1918. činiti deo korpusa predstavljali su Turci naseljeni u Makedoniji i na Kosovu i Metohiji. ${ }^{2}$

U granice Kraljevine SHS ušle su i oblasti današnje Republike Makedonije, koje su bile prilično gusto naseljene turskim stanovništvom. Tursko i ostalo muslimansko stanovništvo do Balkanskih ratova bilo je većinsko u najvećem broju gradova i administrativnih centara delova Makedonije koji su ušli u sastav Kraljevine Srbije. Pod pojmom tursko stanovništvo podrazumeva se etničko šarenilo

\footnotetext{
${ }^{1}$ Мари-Жанин Чалић, Историја Југославије у 20. веку (Београд: Clio, 2013), 104.

${ }^{2}$ Zoran Janjetović, Deca careva pastorčad kraljeva. Nacionalne manjine u Jugoslaviji 1918-1941 (Beograd: INIS, 2005), 37-39.
} 
većeg broja zajednica koje su se zbog muslimanske religije relativno brzo pretapale u turski narod prihvatajući turski jezik, kulturu i običaje. ${ }^{3}$ Ova brza asimilacija muslimanskih zajednica u okvir turskog naroda uticaće i na rezultate popisa u međuratnoj Jugoslaviji, kada će se prilično veliki broj muslimana, posebno u gradovima vardarske Makedonije i Kosova i Metohije, izjasniti kao Turci, odnosno stanovnici sa turskim kao maternjim jezikom (prema tadašnjoj popisnoj metodologiji). To će s druge strane uticati na određene krugove, u ondašnje doba i kasnije, da iskažu sumnju u ispravnost zvaničnih podataka popisa.

\section{Popisi stanovništva u Kraljevini SHS/Jugoslaviji 1921. i 1931.}

Demografska analiza popisnih podataka iz 1921. i 1931. godine, naročito proučavanje nacionalnog sastava i broja pripadnika pojedinačnih naroda i manjina u Jugoslaviji tokom međuratnog perioda, u određenim slučajevima može predstavljati složen zadatak. Administrativne i političke granice u međuratnoj Jugoslaviji prilično brzo su se menjale, a objavljeni podaci odnose se na versku pripadnost $\mathrm{i}$ maternji jezik stanovništva. ${ }^{4} \mathrm{U}$ našem slučaju broj Turaka određujemo prema broju stanovnika koji su kao svoj maternji jezik naveli turski.

U pogledu turske populacije, prve konkretnije statističke podatke o njenom broju (uključujući, razume se, i ostalo stanovništvo) u oblastima koje su prema odredbama Bukureštanskog ugovora (1913) postale sastavni deo Kraljevine Srbije dobijamo na osnovu popisa sprovedenog u ovim oblastima tokom 1913. godine. ${ }^{5}$ Statistički materijal popisa je značajan za istorijsko-demografska proučavanja zbog mogućnosti poređenja sa podacima dobijenim pre Balkanskih ratova, kao i sa objavljenim materijalom popisa iz 1921. godine.

Popis iz 1921. sproveden je u tzv. istorijskim pokrajinama, koje su na jedan ili drugi način postojale i do 1918. godine, za razliku od popisa iz 1931. godine sprovedenog u banovinama formiranim 1929, koje se nisu poklapale ni sa istorijskim niti sa nacionalnim granicama u Kraljevini (osim Dravske banovine). ${ }^{6}$

\footnotetext{
${ }^{3}$ J. Ivanov beleži da se „bitoljski, ohridski, struški, skopski, gostivarski turski stanovnici sastoje uglavnom od Albanaca“. Йорданъ Ивановъ, Българите въ Македония (София, Бьлгарската академия на науките, 1915), lxii-lxiii. Pojedini istraživači, opet, idu u krajnost i čitavo muslimansko stanovništvo u delovima Makedonije i Kosova evidentiraju kao albansko. Albanski istoričar Kristać Prifti u veoma značajnom i voluminoznom delu Popullsia e Kosovës 1831-1912. gotovo bez izuzetka muslimansku populaciju u prištinskom i prizrenskom sandžaku, kao i u najvećem delu skopskog sandžaka u Kosovskom vilajetu, određuje kao albansku. Videti: Kristaq Prifti, Popullsia e Kosovës 1831-1912 (Tiranë: Akademia e Shkencave Shqipërisë, 2014).

${ }^{4}$ Bogoljub Kočović, Etnički i demografski razvoj u Jugoslaviji od 1921. do 1991. godine (po svim zvaničnim a u nekim slučajevima i korigovanim popisima), sveska I (Paris, Bibliothėque Dialogue, 1998), xi.

${ }^{5}$ Мил. Ант. Вујичић, Речник места у Ослобођеној области Старе Србије. По службеним податцима (Београд: Државна штампарија Краљевине Србије, 1914); Српски извори за историјата на македонскиот народ 1912-1914, избор, редакција и коментари Глигор Тодоровски (Скопје: Институт за националну историју, 1979), 90, 107-108, 220; Милош Јагодић, Нови крајеви Србије (1912-1915) (Београд: Филозофски факултет, Универзитет у Београду, 2013), 115-137.

${ }^{6}$ Дефинитивни резултати пописа становништва 1921 године (Сарајево: Општа државна статистика, 1932); В. Kočović, n. $d$., xii.
} 
Podaci popisa iz 1921. godine predstavljaju značajan izvor za poređenje demografskog stanja populacije pre Prvog svetskog rata i posledica koje će ratovi (uključujući i Balkanske) ostaviti na brojnost i strukturu stanovništva u novoj državi. ${ }^{7}$ Śto se nacionalne strukture stanovništva tiče, ona se može utvrditi samo posredno, odnosno pomoću podataka o maternjem jeziku i veroispovesti, pri čemu za određene oblasti podaci mogu biti samo približni. Popisi stanovništva u Kraljevini Jugoslaviji, kao i u slučaju njene posleratne naslednice, imali su - osim statističkog - i politički značaj. Vlasti Kraljevine smatrale su da bi objavljivanje broja pripadnika manjinskih zajednica moglo da ugrozi interese države, zbog čega je Ministarstvo spoljnih poslova pomoću veta odložilo objavljivanje popisnih rezultata iz 1921. godine. ${ }^{8}$

Drugi popis stanovništva u Kraljevini Jugoslaviji organizovan je u periodu od 1. do 20. aprila 1931. godine. ${ }^{9}$ Na ovom popisu, pored maternjeg jezika i veroispovesti, postavljeno je i pitanje o narodnosti ispitanika. ${ }^{10}$ Podaci o maternjem jeziku i narodnosti nisu bili objavljeni do početka Drugog svetskog rata. Pod pitanjem o narodnosti pripadnici svih južnoslovenskih naroda bili su evidentirani kao jedna celina, odnosno kao jedna narodnost - ,jugoslovenska“. ${ }^{11}$ Ukoliko lice nije bilo ,jugoslovenske“ narodnosti, evidentirala se tačna pripadnost određenoj narodnosti. Podaci o nacionalnoj pripadnosti stanovništva u Kraljevini uništeni su tokom nemačkog bombardovanja Beograda, kada je uništen i deo statističkog materijala koji se odnosio na maternji jezik populacije obrađen po opštinama. Ostali su sačuvani podaci obrađeni po srezovima. ${ }^{12}$ Posle okupacije Beograda aprila 1941, nemačke trupe su zaplenile materijal popisa iz 1931. godine, da bi sređene podatke objavile 1943. u Beču. ${ }^{13} \mathrm{U}$ ovoj publikaciji podaci o veroispovesti su ukršteni sa podacima o maternjem jeziku i tabelarno su prikazani po banovinama i srezovima. Posle rata, 1945. godine, deo podataka iz popisa 1931. koji se odnose na maternji jezik i veroispovest objavio je Državni statistički zavod. ${ }^{14}$ I pored toga što je popis iz 1931. formalno predviđao eviden-

\footnotetext{
${ }^{7}$ O ukupnim gubicima stanovništva u vardarskoj Makedoniji, na Kosovu, Metohiji i Sandžaku u periodu 1912-1921. videti: Милош Јагодић, „Процена демографских губитака Срба у периоду 1910-1921“, Српске студије, књ. 6, (2015), 15-22.

${ }^{8}$ Z. Janjetović, $n$. d., 62-63.

${ }^{9}$ Popis je sprovela Opšta državna statistika u Beogradu za Vardarsku, Dunavsku, Moravsku i Zetsku banovinu, kao i za upravu grada Beograda. Statistički zavod u Zagrebu sproveo je popis u Savskoj i Primorskoj banovini, dok je statistički zavod u Sarajevu bio nadležan za sprovođenje popisa u Vrbaskoj i Drinskoj banovini. Definitivni rezultati popisa stanovništva od 31 marta 1931 godine, knjiga I, Prisutno stanovništvo, broj kuća i domaćinstava (Beograd: Državna statistika, 1937), v.

${ }^{10}$ Konačni rezultati popisa stanovništva od 15 marta 1948 godine, knj. IX (Beograd: Savezni zavod za statistiku, 1954), xi.

${ }^{11}$ Isto, xi.

${ }^{12}$ B. Kočović, $n$. $d$., xi.

${ }^{13}$ Die Gliederung der Bevölkerung des ehemaligen Jugoslawien nach Muttersprache und Konfession nach den unveröffentlichen Angaben der Zählung ven 1931 (Wien, 1943).

${ }^{14}$ Stanovništvo predratne Jugoslavije po veroispovesti i maternjem jeziku po popisu od 31.III.1931 godine - pregled po srezovima, Državni statistički ured, serija II, sveska 3 (Beograd: Državna statistika, 1945).
} 
tiranje narodnosti kojoj je lice pripadalo, popisni podaci ne mogu da predstavljaju realan broj pojedinih narodnosti, budući da su sve tzv. jugoslovenske narodnosti morale biti obuhvaćene jednom celinom, odnosno kao jugoslovenska narodnost. ${ }^{15} \mathrm{U}$ suštini, politički kriterijumi u skladu sa tadašnjom politikom integralnog jugoslovenstva mogu predstavljati problem pri sagledavanju nacionalne strukture stanovništva u pojedinim delovima države. ${ }^{16}$

\section{Turci u vardarskoj Makedoniji prema podacima popisa 1921. i 1931. - brojnost i migracije -}

Godine 1921. u Kraljevini SHS živela su 150.332 Turčina, od kojih (sasvim razumljivo) u oblastima koje posle Balkanskih ratova ulaze u sastav Kraljevine Srbije čak 148.019, odnosno 98,46\% od ukupnog broja turskog stanovništva evidentiranog u državi. ${ }^{17} \mathrm{Na}$ prostoru vardarske Makedonije živelo je 118.758 Turaka, dok je u srezovima Kosova i Metohije bilo evidentirano njih $27.915 .{ }^{18}$ Deset godina kasnije, 1931 , njihov broj se smanjio na 132.924 stanovnika. ${ }^{19}$ Popisni podaci iz 1921. i 1931. godine pokazuju da su Turci po brojnosti bili peta manjina u Kraljevini Jugoslaviji. ${ }^{20}$

Zbog njihovih specifičnosti, nacionalne strukture i društvenih uslova vardarsku Makedoniju i Kosovo i Metohiju posmatraćemo zasebno. Kada je reč o brojnosti Turaka u vardarskoj Makedoniji pre Balkanskih ratova, uočljiv je značajan pad broja pripadnika. Prema procenama bugarskog etnografa Jordana Ivanova, neposredno pre Balkanskih ratova u oblastima Makedonije gde je po Bukureštanskom ugovoru bila uspostavljena vlast Kraljevine Srbije (uključujući i strumičku oblast) ${ }^{21}$ živelo je oko 195.000 Turaka. $^{22}$ Glavni raz$\log$ značajnog smanjenja broja Turaka u vardarskoj Makedoniji tokom perioda 1912-1921. za više od 70.000 pripadnika jeste prilično snažan proces iseljavanja. Osim Turaka, u datom periodu različitim intenzitetom iseljavali su se Albanci i makedonski muslimani (Torbeši). ${ }^{23}$

\footnotetext{
${ }^{15} \mathrm{U}$ uputstvu za popunjavanje popisnica bilo je navedeno da je potrebno upisati narodnost kojoj određeno lice pripada (jugoslovenska ili druga). Ukoliko narodnost nije bila jugoslovenska, trebalo je naznačiti narodnost kojoj je lice pripadalo - nemačka, mađarska, turska itd. U uputstvu se navodilo da lice slobodno može navesti svoju narodnost i maternji jezik, a popisni organi u tom pogledu nisu smeli da vrše nikakav pritisak. Konačni rezultati popisa stanovništva od 15 marta 1948 godine, Uvod, xi.

${ }^{16}$ Владан Јовановић, Вардарска бановина 1929-1941 (Београд: ИНИС, 2011 ), 54.

${ }^{17}$ Дефинитивни резултати пописа становништва 1921 године, 3, 87.

${ }^{18}$ Videti: B. Kočović, n. d., 22-25.

${ }^{19}$ Die Gliederung der Bevölkerung des ehemaligen Jugoslawien nach Muttersprache und Konfession, 10.

${ }^{20}$ Prema popisnim podacima iz 1931. najbrojniju manjinu činili su Albanci sa 505.259 pripadnika, odnosno 3,6\% ukupnog stanovništva. Značajne manjinske zajednice predstavljali su i Nemci (499.969 pripadnika), Mađari (468.185) i Rumuni (137.879). Die Gliederung der Bevölkerung des ehemaligen Jugoslawien nach Muttersprache und Konfession, 10.

${ }^{21}$ Strumička oblast je ušla u sastav Kraljevine SHS u skladu sa odredbama Nejskog mirovnog ugovora iz novembra 1919.

22 Й. Ивановъ, н. д., СІІІ.

${ }^{23}$ Analiza statističkih podataka pokazuje umerenije smanjenje albanske populacije u odnosu na
} 
Poraz u Balkanskim ratovima, a zatim i raspad Osmanskog carstva doveli su do suštinskih političkih i civilizacijskih promena u balkanskim oblastima koje su do 1912/13. bile pod osmanskom vlašću. Jednu od posledica tih promena predstavljala je masovna migracija dela Turaka i drugih muslimanskih zajednica u Malu Aziju. ${ }^{24}$ Muslimansko stanovništvo, često vođeno svojim verskim osećanjima, propast Osmanskog carstva doživelo je kao sopstvenu nesreću. ${ }^{25}$ Pored objektivnih faktora, poput straha od nove vlasti, naročito kod nosilaca dotadašnje uprave, razloge za iseljenje možemo tražiti i u neprihvatanju dela muslimanskog stanovništva da živi u hrišćanskoj državi. Ako imamo u vidu privilegovanost muslimanskog stanovništva u Osmanskom carstvu, nove prilike su za deo ove populacije značile neku vrstu degradacije. ${ }^{26}$

Ratovi u periodu 1912-1918. samo su potvrdili pravilo da na Balkanu značajne političke promene najčešće donose etničke promene i izmeštanja. ${ }^{27} \mathrm{Sa}$ punim pravom se u izveštaju Karnegijeve komisije iz 1914. godine ističe da su Prvi balkanski rat i poraz osmanske armije „oslobodili vekovima nakupljane mržnje i osvete. Za nekoliko meseci ugnjetavani hrišćani postali su gospodari i sudije svojim muslimanskim (nekadašnjim) vrhovnim gospodarima“. U suštini, poraz Osmanlija je ,značio nešto više od političke promene, on je promenio odnose osvajača i kmeta“" ${ }^{28}$ Više desetina hiljada muslimana u ovom periodu uputilo se prema Maloj Aziji. ${ }^{29}$

tursku tokom naznačenog perioda u vardarskoj Makedoniji. U međupopisnom periodu (19211931) stanovništvo koje je evidentirano sa albanskim kao maternjim jezikom u srezovima vardarske Makedonije beleži uvećanje za gotovo 20.000. Albanska populacija 1931. beleži najveći porast u srezovima Skoplje, Tetovo, Gostivar, Kumanovo, Kičevo i Struga, u odnosu na prethodni popis. U tetovskom srezu Albanci su predstavljali apsolutnu većinu. Albansko stanovništvo se masovnije iseljavalo iz oblasti gde nije predstavljalo kompaktnu većinu (prilepski, veleški, bitoljski srez), dok je u drugim oblastima ovaj proces umereniji. Albansko stanovništvo $u$ Socijalističkoj Republici Makedoniji (Beograd: Književne novine, 1988), 99-101. Islamizirano stanovništvo vardarske Makedonije pokazalo se kao izuzetno migrantno u vremenu posle Balkanskih ratova, a naročito u međuratnom periodu. Ovo stanovništvo živelo je u kompaktnim zajednicama u skopskom i rekanskom kraju, Župi, Drimkolu, Tikvešu, Pijanecu, u nekoliko sela u Pelagoniji i Pologu. O brojnosti i migracijama islamiziranog makedonskog stanovništva videti: Јован Хаџи Васиљевић, „Муслимани наше крви у Јужној Србији“, Браство, књ. 32, (Београд, 1925), 21-95.

${ }^{24}$ Vladan Jovanović, „Iseljavanje muslimana iz Vardarske banovine - između stihije i državne akcije“, u: Pisati istoriju Jugoslavije: Viđenje srpskog faktora, Zbornik radova, urednik Mile Bjelajac (Beograd: INIS, 2007), 80-81.

${ }^{25}$ Istraživači procesa iseljavanja turskog i muslimanskog stanovništva u prvoj polovini 20. veka objašnjavali su ovu migraciju odsustvom spremnosti Turaka da žive pod „tuđim sudom i tuđom vlašću“. „Dojučerašnji gospodari odlazili su za Malu Aziju gledajući na to kao na sudbinu, kao kismet“. Мита Костић, „Из историје колонизације Јужне Србије крајем прошлог века“, Гласник скопског научног друштва, књ. 12, (Скопље, 1933), 235.

${ }^{26}$ М. Јагодић, Нови крајеви Србије (1912-1915), 305.

${ }^{27}$ Миленко С. Филиповић, „Етничке прилике у Јужној Србији“, у: Споменица двадесетпетогодишњиче ослобођења Јужне Србије 1912-1937, ур. Алекса Јовановић (Скопље: Одбор за прославу двадесетпетогодишњице ослобођења Јужне Србије, 1937), 428.

${ }^{28}$ Поранешните балкански војни (1912-1913), извештај на Карнегиевата балканска комисија (Скопје: Култура, 2000), 103.

${ }^{29}$ Za podatke o ukupnom broju muslimanskog stanovništva iseljenog iz balkanskih zemalja u periodu 1912-1914. videti: Джастин Маккарти, Смърт и изгнание Етническо прочистване 
Manji deo muslimanskog stanovništva povukao se posle poraza 1912. godine sa osmanskom vojskom. To su bili osmanski državni službenici, pripadnici vojske, ili pak lica koja su imala razloga da ne dočekaju novu vlast. Osim njih, i deo „običnog“ stanovništva (u nekim oblastima i čitava sela) povukao se zajedno sa vojskom. Kako je krajem 1912. godine postalo jasno da je Osmansko carstvo nepovratno izgubilo vlast u Makedoniji, migracija se intenzivirala.

Navešćemo nekoliko primera iz istočnih oblasti vardarske Makedonije gde su do Balkanskih ratova Turci predstavljali značajan deo ukupnog stanovništva, a u nekim kazama (srezovima) čak većinu. Popisni podaci iz 1921. godine pokazuju razmere iseljavanja Turaka iz tih oblasti. Te, 1921. godine tursko stanovništvo predstavljalo je većinu jedino u dojranskom srezu gde je od ukupno 8.667 žitelja sa turskim kao maternjim jezikom evidentirano njih 4.367 $(50,4 \%) .{ }^{30} \mathrm{U}$ radoviškom srezu, koji se poklapa sa nekadašnjom radoviškom kazom, prema procenama J. Ivanova 1912. godine živelo je 12.560 Turaka $(57 \%),{ }^{31}$ dok se 1921. njihov broj smanjio na $7.056,{ }^{32}$ odnosno broj Turaka u radoviškoj oblasti za nepunu deceniju, ne računajući prirodni prirast, umanjio se za 43\%. Sličan slučaj je sa kočanskim srezom. Godine 1912. u kočanskoj kazi živelo je 14.620 Turaka (41\%), dok je 1921. evidentirano njih $6.739^{33}(26,2 \%)$. Broj Turaka u kočanskoj oblasti smanjio se za 54\%. Samo iz sela u kočanskom srezu za vreme Balkanskih ratova iselilo se najmanje 400 domaćinstava. ${ }^{34}$

Istovetan proces odvijao se u Ovčem polju, oblasti u kojoj je do 1912. godine brojnost turskog stanovništva bila značajna. ${ }^{35}$ Prostor na kojem su 1912 13. godine srpske vlasti formirale Svetonikolski-ovčepoljski srez do Balkanskih ratova bio je deo nahije Berićetli, ${ }^{36} \mathrm{u}$ okviru štipske kaze. Prema podacima srpskih vlasti sa popisa sprovedenog februara i marta 1913, u ovčepoljskom srezu živelo je 15.275 stanovnika u 2.606 kuća, od kojih je „1.270 kuća ili 47,8\% bilo bugarskih, a 1.336 kuća ili 51,3\% bilo turskih“. ${ }^{37}$

на османските мюслимани 1821-1922 (София: Университетско издателство „Св. Климент Охридски“, 2010), 169-215; В. Јовановић, Вардарска бановина 1929-1941, 106-107.

30 Дефинитивни резултати пописа становништва 1921 године, 118.

${ }^{31}$ Й. Иванов, н. Ә., CIII. Prema K. Priftiju, Turci su u radoviškoj kazi u prvoj deceniji 20. veka činili 57,52\% stanovništva. K. Prifti, op. cit., 914-915.

32 Дефинитивни резултати пописа становништва 1921 године, 95-96.

${ }^{33}$ Исто, 92-93.

34 Iz kočanske oblasti tokom 1912. godine tursko stanovništvo se u celini iselilo iz sela Donji Polog, Grdovci i Orizari. Iz Orizara se zajedno sa turskom vojskom povuklo i tursko stanovništvo, oko 90 domaćinstava. Iz Istibanje se 1912. od ukupno 200 turskih domaćinstava u M. Aziju iselilo njih 170. Iz sela Teranci, od 180 u M. Aziju se iselilo oko 30 domaćinstava, itd. Јован Ф. Трифуноски, Кочанска котлина, сеоска насеља и становништво (Скопје: б. и., 1970), $49,79,100-107,128,145$.

${ }^{35}$ U Ovčem polju tursko stanovništvo je naseljeno tokom prvih talasa kolonizacije koju je sprovodila Osmanska imperija. O tome svedoči i deo toponima u oblasti. Broj Turaka, kao i u drugim oblastima Makedonije, uvećao se posle 1878. stanovništvom čiji su veći deo činili muhadžiri iz Srbije i Bugarske.

${ }^{36}$ Салнаме на Вилаетот Косово, превод од Османско - турски јазик, превод и коментари Драги Горгиев и Ахмед Шериф (Скопје: Сојуз на Турските Невладини Организации во Македонија, 2012), 202-203.

${ }^{37}$ М. Јагодић, Нови крајеви Србије (1912-1915), 118. Okružni načelnik Lj. Grković u izveštaju za januar 1914. navodi da „u mestu Sveti Nikole živi 1.892 stanovnika, pola Srba, pola muslimana“. Српски извори за историјата на македонскиот народ 1912-1914, 271. 
Kao i u većini oblasti u Makedoniji, posle Balkanskih ratova i Ovče polje, odnosno ovčepoljski srez zahvatio je snažan proces promena etničke i verske strukture stanovništva. Čiflik-sajbije su prodavale zemlju i migrirale u Malu Aziju. Njih je sledio deo ostalog turskog stanovništva u oblasti, pa je taj proces uticao na značajan pad turske populacije. Pri povlačenju turske vojne i administrativne vlasti povuklo se i čitavo tursko stanovništvo iz sela Mustafino, Erdželija, kao i deo Turaka iz drugih sela. ${ }^{38}$

Sličan proces odvijao se u krivopalanačkom srezu. Prema procenama J. Ivanova, pred početak Balkanskih ratova u tadašnjoj krivopalanačkoj kazi živelo je 2.700 Turaka. ${ }^{39}$ Karakteristično za ovu oblast jeste da su Turci živeli samo u administrativnom centru kaze Krivoj Palanci, u kojoj je krajem 19. veka bilo 2.500 turskih žitelja, odnosno $57,6 \%$ od ukupnog broja stanovnika mesta. ${ }^{40} \mathrm{Srp}-$ ska uprava je sprovela popis odmah po uspostavljanju vlasti u krivopalanačkoj oblasti. Prema podacima koje je Vrhovnoj komandi poslao major P. Bajalović, u gradu su živela 2.694 Turčina u oko 700 kuća. U selima nije bilo muslimanskog stanovništva. ${ }^{41}$ Popisni podaci pokazuju da je 1921. godine u K. Palanci ostalo da živi 675 Turaka, odnosno toliko stanovnika sa turskim kao maternjim jezikom. ${ }^{42}$ Značajnog smanjenja turske populacije bilo je i u kratovskom srezu. Godine 1912. u kratovskoj kazi živelo je 3.850 Turaka, odnosno 16,3\% ukupnog stanovništva. ${ }^{43}$ Popis iz 1921. pokazuje da su u kratovskom srezu živela 773 Turčina (3,9\%), od kojih njih 474 u gradiću Kratovo. ${ }^{44}$

Naročito veliki pad ukupnog broja stanovnika, uključujući i Turke, beleži se u oblastima koje su se za vreme Prvog svetskog rata nalazile na liniji fronta. ${ }^{45}$ Navešćemo primer đevđelijskog sreza. Deo đevđelijske kaze, prema odredbama

${ }^{38}$ Iz pomenutih sela u Malu Aziju iselilo se oko 200 turskih domaćinstava. Jovan F. Trifunoski, „Ovčepoljska kotlina“, Zbornik za narodni život i običaje Južnih Slavena, knj. 42, (1964), 643, $705,731,752,755$.

${ }^{39}$ Й. Иванов, н. д., СІІІ.

40 Васил Кънчов, Македония етнография и статистика (София: Акад. изд. проф. Марин Дринов, 1996), (2. репринт издање), 224

${ }^{41}$ М. Јагодић, Нови крајеви Србије (1912-1915), 131. Podaci srpskih vlasti o broju turskog stanovništva u K. Palanci gotovo se poklapaju sa procenama Ivanova za 1912. godinu.

42 Дефинитивни резултати пописа становништва 1921 године, 102-103.

${ }^{43}$ Й. Иванов, н. д., СІІІ.

${ }_{44}^{44}$ Дефинитивни резултати пописа становништва 1921 године, 100-101.

${ }^{45}$ Karakteristično je da neki gradovi, naročito oni locirani na liniji solunskog (makedonskog) fronta za vreme Prvog svetskog rata, beleže veliki pad broja stanovnika, a neki su gotovo nestali sa geografske karte. Bitolj je 1913. imao 48.370 stanovnika, da bi samo osam godina kasnije, 1921, kao posledica rata, ovaj nekadašnji važan centar evropske Turske postao pogranični grad odsečen od svog ekonomskog zaleđa, sa samo 28.420 stanovnika (Исто, 88). U ovom kontekstu pomenućemo i Dojran. U nekada prosperitetnom mestu blizu Soluna pred početak Balkanskih ratova bilo je 1.650 kuća sa oko 8.000 stanovnika, polovina hrišćana, polovina muslimana. Кирил Хаджидинев, Дойран (София: Издателство на националния сьвет на отечествения фронт, 1960), 31. U vreme uspostavljanja srpske vlasti 1913. godine Dojran je imao 4.032 stanovnika. М. А. Вујичић, н. д., 147. Godine 1925. imao je status varošice verovatno samo kao podsećanje na raniji status budući da je u njemu živelo samo 328 stanovnika i da je bio manji od većine okolnih sela. Речник места (Београд: Народна просвета, 1925), 17. 
Bukureštanskog ugovora, ušao je u sastav Kraljevine Srbije. Na ovom prostoru, prema procenama V. Kančova, krajem 19. veka živela su 19.024 stanovnika, od kojih 5.115 (26,9\%) Turaka. ${ }^{46}$ Vojne operacije u periodu 1915-1918. kao i iseljavanje doprineli su da 1921. godine u đevđelijskom srezu budu evidentirana samo 293 Turčina. $^{47}$

Do smanjenja turske populacije došlo je i u drugim srezovima, iako u zapadnim oblastima vardarske Makedonije popis iz 1921. godine evidentira stanovništvo sa turskim kao maternjim jezikom uglavnom u gradovima. U ohridskom srezu čak 99\% turskog stanovništva živi u Ohridu, slično kao u donjepološkom srezu, gde su u Tetovu evidentirana $93 \%$ od sveukupnog turskog stanovništva. U bitoljskom srezu gradsko tursko stanovništvo iznosi $85 \%$, skopskom $82,5 \%,{ }^{48}$ struškom $58,2 \%$, a u gornjepološkom $52 \%{ }^{49}$

Veće grupe turskog stanovništva van gradskih i administrativnih centara beleže se u Župi, ${ }^{50}$ u Pelagoniji oko Kremenice i Kanatlaraca ${ }^{51}$ i u Gornjem Pologu. ${ }^{52}$ Navešćemo primere nekoliko gradova. Prema popisnim rezultatima iz 1921. godine, stanovništvo sa turskim kao maternjim jezikom je od gradova i administrativnih centara bilo većina samo u Gostivaru, gde je živelo 3.747 stanovnika sa turskim kao maternjim jezikom, odnosno $77,5 \%$ od gradske populacije. ${ }^{53} \mathrm{Za}$ razliku od većine gradova u Makedoniji, u Gostivaru se ne beleži pad broja stanovnika u periodu 1913-1921. godine. Prema izveštaju načelnika tetovskog okruga M. Dorontića, krajem aprila 1913. u Gostivaru su živela 4.383 stanovnika, od kojih „276 Srba i 4.107 Turaka“. 54 Po statistici bugarskih vlasti od 1916. godine u gradu Gostivaru je živelo oko 4.000 Albanaca, ,koji se turciziraju i žele da govore turski““. ${ }^{55} \mathrm{U}$ susednom pološkom gradu Tetovu među

${ }^{46}$ U ukupan broj stanovnika uračunati su stanovnici mesta koja su 1913. godine ušla u sastav Kraljevine Srbije (uporediti: В. Кънчов, Македония, 152-153).

47 Дефинитивни резултати пописа становништва 1921 године, 121. Primer za smanjenje broja turskog stanovništva u đevđelijskom srezu predstavlja selo Gorničet, u kome je (prema procenama) krajem 19. veka živelo 1.100 Turaka (В. Кънчов, Македония, 152). Kao posledica iseljavanja za vreme Balkanskih ratova i posle toga, na popisu 1921. u opštini Mojin, u čijem sastavu je bilo selo Gorničet, nije evidentiran nijedan Turčin (Дефинитивни резултати пописа становништва 1921 године, 121).

${ }^{48}$ Realan broj turskog stanovništva u skopskoj okolini (bez grada Skoplja) manji je od zvanično evidentiranih 2.958 stanovnika, jer je makedonsko muslimansko stanovništvo u opštini Gornji Količani u okolini Skoplja evidentirano kao tursko. Ovakve nepreciznosti zvanične statistike iz 1921. zabeležili su još tridesetih godina istraživači ovih oblasti. Videti: М. С. Филиповић, „Етничке прилике у Јужној Србији“, 424.

49 Дефинитивни резултати пописа становништва 1921 године, 88-123.

${ }^{50} \mathrm{O}$ broju, strukturi i migracijama turskog i ostalog stanovništva u debarskoj župi: Бранислав Русић, Жупа Дебарска (Скопље: Филозофски факултет, 1957).

51 Јован Ф. Трифуноски, Битољско-прилепска котлина, антропогеографска проучавања (Београд: Српска академија наука и уметности, 1998), 69-72.

52 O turskom stanovništvu u Pologu videti: Rudolf Petrović, Polog: antropogeografski prikaz (Zagreb: Preporod, 1942), 9-35; Јован Ф. Трифуноски, Полог (антропогеографска проучавања) (Београд: Српска академија наука и уметности, 1976), 80-84.

${ }_{53}$ Дефинитивни резултати пописа становниттва 1921 године, 116-117.

${ }^{54}$ Српски извори за историјата на македонскиот народ 1912-1914, 110.

55 Димитар Г. Гаджанов, „Мюсюманското население в новоосвободените земи“, в: Научна 
muslimanima tokom 1921. godine stanovništvo sa turskim jezikom predstavljalo je većinu. Od ukupno 15.119 stanovnika, 8.193 (54,2\%) bili su muslimani, a $6.900(45,6 \%)$ pravoslavni. Od muslimanskog stanovništva kao Turci po maternjem jeziku popisana su 6.432 stanovnika, odnosno $42,5 \%$ ukupne populacije u gradu. ${ }^{56}$ Broj stanovnika u gradu Tetovu u odnosu na stanje iz 1913. godine smanjio se za gotovo 5.000, to jest za četvrtinu, što predstavlja prosek u odnosu na smanjenje populacije u drugim gradovima Makedonije u ovom periodu. ${ }^{57}$

Interesantna je analiza Rudolfa Petrovića, jednog od istraživača Pologa $u$ međuratnom periodu, koji za brojnost i odnos turskog i albanskog stanovništva u Tetovu i Gostivaru beleži: „Kod doseljenih Arbanasa, naročito u gradovima Tetovo i Gostivar i njihovoj bliskoj okolini, nastupio je proces turciziranja pre svega zbog snažno ukorenjenog islama i zajedničkog života sa Turcima, zbog čega se Arbanasi koji žive u gradovima ili blizu njih dobrim delom osećaju kao Turci. To je razlog zašto je u novije vreme teško razdvojiti Turke od turciziranih Arbanasa. Ova poteškoća unosi zbrku i u statistiku. “58 Navedenu ,zbrku u statistici“ ilustruju podaci o broju Turaka prema prvom posleratnom popisu u FNRJ 1948. godine. U gradu Tetovu evidentirana su 302 Turčina, a u Gostivaru samo 53. U gostivarskoj okolini, gde je 1931. godine registrovano 7.705 stanovnika sa turskim kao maternjim jezikom, u drugačijim društvenim i političkim uslovima 1948. godine evidentirano je samo 117 Turaka. $^{59}$

Značajan procenat turskog stanovništva 1921. godine evidentiran je i u Ohridu. Prema popisnim podacima, u Ohridu je živelo 9.587 stanovnika, od kojih 5.148 pravoslavnih i 4.331 musliman. ${ }^{60}$ Među gradskim muslimanima dominirala je populacija sa turskim kao maternjim jezikom, i to 38,3\% od ukupnog stanovništva grada, dok su stanovnici evidentirani sa arnautskim jezikom bili zastupljeni sa $6 \%$. Interesantna su istraživanja antropogeografa Atanasija Uroševića, koji je vršio terenska ispitivanja u Ohridu, prema kojima veći deo muslimanskog stanovništva Ohrida nije bio turskog porekla. ${ }^{61}$

Slični procesi događali su se u Skoplju. Pred početak Balkanskih ratova muslimansko stanovništvo predstavljalo je većinu u gradu. Srpske vlasti su početkom novembra 1912, nepun mesec po uspostavljanju vlasti, procenjivale da u gradu živi do 50.000 stanovnika, većinom muslimana, od kojih je ,,veći deo

експедиция в Македония и Поморавието, 1916 г., съст., Петър Хр. Петров (София, Университетско издателство „Св. Климент Охридски“, 1993).

56 Дефинитивни резултати пописа становништва 1921 године, 119.

${ }^{57}$ U gradu Tetovu 1913. godine popisano je ukupno 20.070 stanovnika, u 3.600 domova, od čega: „1.800 turskih, 1.263 bugarska i 537 srpskih“. М. Јагодић, Нови крајеви Србије (1912-1915), 118.

58 R. Petrović, $n$. d., 20.

${ }^{59}$ Konačni rezultati popisa stanovništva od 15 marta 1948 godine, 440, 450.

60 Дефинитивни резултати пописа становништва 1921 године, 104.

${ }^{61}$ Muslimansko stanovništvo raznih narodnosti koje se doseljavalo u Ohrid brzo se pretapalo u Turke, nosioce islama i gradske kulture. Ovaj proces obuhvatio je i doseljene Albancemuslimane, čiji su najstariji rodovi živeli u gradu od sredine 18. veka, a potiču iz oblasti bliskih teritoriji današnje Albanije ili iz debarskog kraja. Albanskih doseljenika pretopljenih u lokalno tursko stanovništvo bilo je i iz južne Albanije, o čemu svedoči često prezime Тоska. Атанасије Урошевић, Охрид географска монографија (Скопље: Филозофски факултет на Универзитетот, 1957), 14-16. 
starosedelaca, dok manji deo predstavljaju doseljeni Arnauti““ ${ }^{62}$ Prema podacima popisa u proleće 1913. u tadašnjem skopskom srezu, uključujući i grad, živelo je 98.748 stanovnika. U samom Skoplju registrovana su 47.384 stanovnika. ${ }^{63}$ Popis iz 1921. godine pokazuje da je Skoplje imalo 40.666 stanovnika, od kojih 13.980 Turaka $(34,4 \%){ }^{64}$ I posle Balkanskih ratova Turci su predstavljali značajan deo gradskog stanovništva. Do 1912. godine među Turcima u Skoplju, pored potomaka starih anadolskih kolonista i pripadnika osmanske administracije, znatan deo čini muslimansko stanovništvo (albansko, bosanski muhadžiri i lokalno islamizirano stanovništvo). Kao i u većini gradskih centara na Balkanu, za vreme osmanske vladavine u Skoplju turski uticaj, kultura i leksika su brzo prodirali među ostalo muslimansko stanovništvo, koje se za relativno kratko vreme turciziralo. Takav proces je za Skoplje bio karakterističan i u međuratnom periodu. ${ }^{65}$ U skopskom srezu tokom 1931. godine evidentirana su 16.263 stanovnika sa turskim kao maternjim jezikom, odnosno 12,7\% ukupnog stanovništva sreza. ${ }^{66}$ Smanjenje u odnosu na 1921 . godinu bilo je minimalno.

Iseljavanje turskog stanovništva iz vardarske Makedonije nastavilo se $\mathrm{u}$ trećoj deceniji 20. veka. Podaci popisa iz 1921. i 1931. pokazuju da je u vardarskoj Makedoniji došlo do smanjenja turskog stanovništva: od 118.758 u 1921. na 105.407 u 1931. godini. U najvećem delu srezova broj Turaka se smanjio ili je beležio stagnaciju. Dvadesetih godina iseljavali su se kako gradski Turci tako i deo turskog stanovništva iz sela, naročito bogatiji sloj. Do većeg pada broja Turaka došlo je u štipskom, veleškom, kočanskom, bitoljskom, ovčepoljskom, kratovskom, kavadarskom, negotinskom i drugim srezovima. U prilepskom, mariovskom, strumičkom, radoviškom i donje i gornjepološkom srezu došlo je do stabilizovanja, pa čak i do blagog porasta evidentiranog stanovništva sa turskim kao maternjim jezikom.

Navešćemo demografske podatke iz ovčepoljskog i kočanskog sreza, kao i iz veleškog sreza, u kome se broj turskog stanovništva od 9.398 u 1921. godini smanjio na 5.207 stanovnika 1931. godine. Iz Ovčeg polja po svršetku Prvog svetskog rata, a posebno u periodu 1923-1928. godine, iselio se veliki broj turskih porodica. Podaci popisa održanog 1931. pokazuju da su u pomenutom srezu živela 4.894 Turčina,${ }^{67}$ odnosno 22,3\% ukupnog broja stanovnika. U odnosu na 1921. godinu, ne računajući prirodni rast, broj Turaka se smanjio za 1.376 stanovnika. Gotovo da nema naseljenog mesta u srezu iz kojeg se nije iselilo po nekoliko desetina domaćinstava. ${ }^{68} \mathrm{U}$ administrativnom centru sreza, gradiću Sveti Nikola, 1921. godine

\footnotetext{
${ }^{62}$ Српски извори за историјата на македонскиот народ 1912-1914, 60. V. Kančov, pišući o turskom stanovništvu u Skoplju krajem 19. veka, navodi da je bar trećina Turaka u gradu albanskog porekla. Васил Кънчов, Избрани произведения, том II (София: Издателство наука и искуство, 1970), 30.

${ }^{63}$ М. А. Вујичић, Н. д., 5, 132-134.

${ }^{64}$ Дефинитивни резултати пописа становниттва 1921 године, 112-113.

${ }^{65}$ Jovan F. Trifunoski, ,Savremeni etnički procesi u Skoplju“, Etnološki pregled, br. 13, (1975), 126-127.

${ }^{66}$ Die Gliederung der Bevölkerung des ehemaligen Jugoslawien nach Muttersprache und Konfession, 344 .

${ }^{67} \mathrm{Ibid}, 335$.

${ }^{68}$ Tokom dvadesetih godina iselili su se Turci iz ovčepoljskih sela Peširovo, Amazabegovo, Malo
} 
bilo je evidentirano 690 Turaka, ${ }^{69}$ dok je 1931. zbog iseljenja njihov broj opao na 87 stanovnika, koji su živeli u 17 domaćinstava. ${ }^{70}$

Slični procesi su se dešavali u kočanskom srezu. Opadanje broja turskih stanovnika kao posledica iseljavanja nastavilo se i tokom dvadesetih godina. Podaci popisa iz 1931. godine pokazuju da je u kočanskom srezu živelo 5.376 Turaka, ${ }^{71}$ odnosno $16,1 \%$ ukupnog stanovništva. Broj Turaka u odnosu na 1921. godinu umanjen je za 1.363 žitelja. ${ }^{72}$ Znatnog iseljavanja bilo je i u Povardarju. U veleškom srezu 1921. godine evidentirano je 9.398 Turaka, odnosno 21,7\% ukupnog stanovništva. Proces iseljavanja Turaka iz veleške oblasti započeo je sa Balkanskim ratovima. Najveće tursko selo do ovih ratova u veleškoj kazi bili su Ivankovci u kojima je krajem 19. veka, prema procenama V. Kančova, živelo 1.100 stanovnika. ${ }^{73}$ Neposredno pred Balkanske ratove u selu je bilo oko 300 turskih domaćinstava. Tokom ovih ratova počelo je njihovo iseljavanje pa su 1931. godine ostala 154 turska domaćinstva. Najmasovnije je bilo iseljavanje 1928/29. godine, kada se iz Ivankovaca u Tursku iselilo 46 turskih porodica. ${ }^{74}$ Prema procenama M. Filipovića, iz pomenutog i nekoliko okolnih sela od Balkanskih ratova do početka tridesetih godina u Tursku se iselilo oko 200 domaćinstava. ${ }^{75}$ Godine 1931. u veleškom srezu živelo je 5.207 Turaka. $^{76}$

Zbog iseljavanja Turaka iz vardarske Makedonije u međuratnom periodu, njihov broj se stalno smanjivao. I po popisu iz 1948. godine vidi se da se broj Turaka u odnosu na prethodni popis iz 1931. smanjio za oko 10.000. Specifičnosti popisne metodologije (izjašnjavanje po maternjem jeziku), kao i političke prilike u Kraljevini Jugoslaviji bile su razlog da se deo muslimanskog stanovništva u gradovima severne i severozapadne vardarske Makedonije izjašnjavao kao Turci po maternjem jeziku. I pored toga, popisi stanovnika u Kraljevini Jugoslaviji daju relativno tačnu predstavu o broju i strukturi Turaka u vardarskoj Makedoniji.

Crnilište, kao i dobar deo turskog stanovništva u Gorobincima, Svetom Nikoli i drugim selima. Iz pomenutih i drugih sela u srezu u Tursku se iselilo nekoliko stotina domaćinstava. J. F. Trifunoski, „Ovčepoljska kotlina“, 643, 670, 699, 701, 703, 708, 722, 758, 762.

${ }^{69}$ Дефинитивни резултати пописа становниттва 1921 године, 92-93.

${ }^{70}$ Манојло Р. Чучковић, „Варошица Свети Николе на Овчем Пољу“, Гласник скопског научног друштва, књ. XV-XVI, (1936), 281.

${ }^{71}$ Die Gliederung der Bevölkerung des ehemaligen Jugoslawien nach Muttersprache und Konfession, 324.

${ }^{72}$ Tokom dvadesetih i tridesetih godina iz kočanskog sreza u Tursku se iselilo oko 500 turskih domaćinstava. J. Ф. Трифуноски, Кочанска котлина, 82-147.

${ }^{73}$ В. Кънчов, Македония, 157.

74 Миленко Филиповић, Северна велешка села (Београд: Српска краљевска академија, 1935), 519, 532.

${ }^{75}$ Исто, 532.

${ }^{76}$ Uporediti: Jovan F. Trifunoski, „Oblast Babune i Topolke“, Zbornik za narodni život i običaje Južnih Slavena, knj. 47, (Zagreb, 1977), 193, 252-255. 
Turci u oblastima na Kosovu i Metohiji prema popisima iz 1921. i 1931.

Za razliku od vardarske Makedonije - gde popisi iz 1921. i 1931. godine evidentiraju prisustvo turskog stanovništva u više oblasti koje je bilo gotovo ravnomerno raspoređeno $\mathrm{u}$ gradovima $\mathrm{i}$ administrativnim centrima srezova, kao i u selima - u oblastima na Kosovu i Metohiji tursko stanovništvo je evidentirano skoro isključivo u gradovima. Godine 1921. u zvečanskom, kosovskom, prizrenskom i metohijskim okrugu, uključujući i kačanički srez, koji je bio deo skopskog okruga, evidentirano je 27.915 Turaka, odnosno stanovnika koji su na popisu naveli turski kao maternji jezik. ${ }^{77}$ Od ukupno evidentiranih Turaka, njih 89,98\% živelo je u gradovima, odnosno administrativnim centrima srezova, u Prištini, Prizrenu, Kosovskoj Mitrovici, Vučitrnu, Gnjilanu, Peći i Uroševcu. U ostalim gradovima njihovo prisustvo je minimalno. U Prizrenu, prema zvaničnim podacima, živelo je 9.189 stanovnika sa turskim kao maternjim jezikom, odnosno 56\% ukupnog stanovništva u gradu. Slično je bilo u Prištini, gde je evidentirano 7.115 stanovnika sa turskim kao maternjim jezikom, odnosno $49,6 \%$ stanovništva u gradu. ${ }^{78}$ Prema zvaničnim podacima, stanovništvo sa turskim maternjim jezikom predstavljalo je većinu u Vučitrnu. Od ukupno 4.667 stanovnika 1921. godine, 1.881 stanovnik $(40,30 \%)$ evidentiran je sa turskim kao maternjim jezikom, nasuprot 1.112 sa „arnautskim jezikom“. Slično je u K. Mitrovici, gde je od ukupno 10.045 stanovnika evidentirano 3.287 Turaka prema maternjem jeziku. Značajnije prisustvo turskog stanovništva zabeleženo je u Gnjilanu (2.013), Peći (1.261) i Uroševcu (212)..$^{79}$

Prisustvo turskog stanovništva u prištinskom i prizrenskom okrugu registrovano je i na popisu koje su sprovele srpske vlasti u proleće 1913. godine. Prema ovim podacima, u prištinskom okrugu od ukupno 240.209 stanovnika njih 19.683 bili su Turci, od kojih su 18.393 živela u gradovima Priština, Vučitrn i Gnjilane. ${ }^{80} \mathrm{U}$ prizrenskom okrugu na pomenutom popisu evidentirano je 23.748 Turaka, to jest $10,4 \%$ ukupnog stanovništva okruga. ${ }^{81} \mathrm{Za}$ razliku od popisne evidencije srpskih vlasti, prema procenama bugarskih vlasti, čija je vojska u jesen 1915. godine okupirala ovaj prostor, tu je živeo izrazito manji broj turskih stanovnika. ${ }^{82}$

77 Дефинитивни резултати пописа становништва 1921 године, 94-111, 115; В. Kос̌оvić, $n$. d., 22-23.

${ }^{78}$ Дефинитивни резултати пописа становништва 1921 године, 94-107.

${ }^{79}$ Исто, 95-99.

${ }^{80}$ Prema podacima tog popisa, u gradovima Vučitrn i Gnjilane nije živeo nijedan Albanac. M. Јагодић, Нови крајеви Србије (1912-1915), 126-127.

${ }^{81}$ Исто, 129.

${ }^{82}$ Govoreći o Prizrenu u svom izveštaju Štabu bugarske armije iz 1916. godine, Anastas Iširkov navodi: „Razgraničenje među Albancima muhamedancima i Turcima ne može da se napravi i evidentirani Turci najvećim delom su Albanci po jeziku“. Prema statistici bugarskih vlasti u Prištini, na primer, uopšte nije evidentirano prisustvo turskog stanovništva. Анастас Иширков, „Пьтуване в Македония и Поморавия“, Научна експедиция в Македония и Поморавието, 1916 г., съст., Петър Хр. Петров (София, Университетско издателство „Св. Климент Охридски“, 1993), 108-109. 
Statistika, međutim, ne može promeniti dinamiku života i političku realnost. Nesumnjivo su u prištinskom i prizrenskom okrugu do Balkanskih ratova vodeću ulogu u demografskom i političkom smislu imali Albanci. ${ }^{83}$ Istraživači prilika u Kosovskom vilajetu krajem 19. veka zaključili su sledeće: „Arnauti imaju apsolutnu vlast i usmeravaju vladanje administracije. Jaki arnautski begovi samostalno upravljaju arnautskim opštinama. Oni državi ne daju ni vojnike, ni danak." ${ }^{\text {"84 }}$

Kao i prilikom popisa iz 1921. godine, i drugim popisom u Kraljevini Jugoslaviji 1931. godine evidentirano je prisustvo 23.700 stanovnika sa turskim jezikom. Najveći deo ovog stanovništva je popisan u šarplaninskom srezu, kojem je pripadao grad Prizren (9.145), gračaničkom srezu sa gradom Prištinom (6.353), gnjilanskom (2.212), vučitrnskom (1.731), pećkom (1.667), kosovskomitrovačkom (1.307) i podrimskom srezu sa 900 Turaka. Navedeni srezovi administrativno su pripadali Vardarskoj, Moravskoj i Zetskoj banovini. ${ }^{85}$

Za razliku od zvaničnih podataka dvaju popisa u međuratnoj Jugoslaviji, podaci istraživača o brojnosti turskog stanovništva na Kosovu i Metohiji iz ovog perioda znatno se razlikuju. Navešćemo primer Atanasija Uroševića, čiji podaci dobijeni prilikom detaljnih terenskih istraživanja Kosova daju sasvim drugačiju sliku strukture muslimanskog stanovništva u više kosovskih gradova. U gradu Vučitrnu 1921. godine živeo je 1.881 stanovnik sa turskim jezikom, dok je deset godina kasnije u vučitrnskom srezu (nesumnjivo, u gradu) evidentiran 1.731 Turčin. Pišući u svojoj studiji o stanovništvu u gradu tridesetih godina, A. Urošević navodi samo „četiri roda sa pravim turskim poreklom“. ${ }^{86}$ Nesumnjivo se na dva popisa deo albanskog i drugog muslimanskog stanovništva izjasnio ili je, pak, evidentiran sa turskim kao maternjim jezikom. Istovetan je slučaj u Gnjilanu, gde je 1921. godine registrovano 2.013 stanovnika sa turskim kao maternjim jezikom, dok početkom tridesetih godina A. Urošević navodi da je „veći deo muslimana sa turskim jezikom arbanaškog porekla“. Samo dva roda u gradu, po njegovom mišljenju, imala su tursko poreklo. ${ }^{87} \mathrm{O}$ stanovništvu u Prištini koje je na popisu 1921. godine evidentirano sa turskim jezikom, Urošević piše da su uglavnom „arbanaškog porekla“ $i$ u grad doseljeni iz okolnih kosovskih i metohijskih oblasti ${ }^{88}$ Ista konstatacija važi za K. Mitrovicu u kojoj su pripadnici turskog maternjeg jezika 1921. godine sačinjavali $32 \%$ gradske populacije. ${ }^{89}$ To su uglavnom bili lokalni Albanci koji su pod uti-

\footnotetext{
${ }^{83}$ Videti: Милош Јагодић, Српско-албански односи у Косовском вилајету (Београд: Завод за уџбенике, 2009).

${ }^{84}$ В. Кънчов, Избрани произведения, 54. V. Kančov navodi da „u gradovima Stare Srbije Turaka ima samo u svojstvu činovnika i vojnika“. Исто, 53.

${ }^{85}$ Die Gliederung der Bevölkerung des ehemaligen Jugoslawien nach Muttersprache und Konfession, 212, 315, 319, 337, 395; B. Kočović, n. d., sveska II, 209.

${ }^{86}$ Атанасије Урошевић, „Вучитрн“, Гласник скопског научног друштва, књ. ХІХ, (1938), 223.

${ }^{87}$ Атанасије Урошевић, Гьилане (Београд: б. и., 1931), 49.

${ }^{88}$ Атанасије Урошевић, О Косову антропогеографске студије и други списи (Приштина, Гьилане: Институт за српску културу, 2001), 274-276.

${ }^{89}$ Дефинитивни резултати пописа становништва 1921 године, 94-95.
} 
cajem turske kulture i gradskog života prilikom popisa navodili da je turski njihov maternji jezik. ${ }^{90}$ Deset godina kasnije, na popisu 1931. godine njihov broj se smanjio za više od $50 \% .^{91}$

Za razliku od gradova, u selima na Kosovu i Metohiji veoma mali procenat muslimanskog stanovništva naveo je na popisima turski jezik kao maternji, iako u manjem delu ovde postoji nepoklapanje sa zvaničnom statistikom i terenskim istraživanjima. Navešćemo primer Prizrenskog podgora. U selu Mušutište, iako je bilo samo nekoliko turskih porodica, na popisu 1921. godine evidentirano je 296 lica sa turskim jezikom. Nesumnjivo, deo Albanaca naveo je turski kao maternji jezik. ${ }^{92}$

Slično kao u vardarskoj Makedoniji, deo albanskog i drugog muslimanskog stanovništva na Kosovu i Metohiji pripadnost muslimanskoj veroispovesti vezuje za turski narod zbog nedovoljno izgrađene nacionalne svesti, tradicija koje je muslimansko stanovništvo formiralo u prošlosti pre svega u gradskim sredinama, a ponekad i zbog trenutne političke situacije. ${ }^{93}$ Ovo poslednje naročito je očigledno na prvom posleratnom popisu u Jugoslaviji 1948. godine, koji se sprovodio u sasvim drugačijim političkim uslovima za razliku od popisa između dva svetska rata. Na ovom popisu samo 1.315 stanovnika tadašnje Autonomne Kosovsko-metohijske oblasti izjasnili su se kao Turci. Kao primere ćemo navesti gradove u kojima je na popisima u međuratnom periodu bilo i po nekoliko hiljada registrovanih Turaka, odnosno stanovnika sa turskim kao maternjim jezikom. U Prizrenu je na popisu 1948. godine evidentirano 35 Turaka, Prištini 65, K. Mitrovici 50, Gnjilanu 296, Peći 3, a u Vučitrnu nijedan. ${ }^{94}$ Pet godina kasnije, u vidno izmenjenim političkim uslovima, kada započinje novi i prilično masovan proces iseljavanja turskog i muslimanskog stanovništva iz FNRJ, ponovo dolazi do značajnog uvećanja broja deklarisanih Turaka.

Posle popisa 1931. godine nastavljen je proces smanjenja broja Turaka kao posledica njihovog iseljavanja. Popisni rezultati pokazali su da se, za razliku od Turaka, broj Albanaca u periodu 1921-1931. uvećao za gotovo 70.000. Političko iskustvo balkanskih država pretočeno u Lozanski ugovor (1923), potpisan posle grčko-turskog rata i obavezna razmena grčkog i tur-

\footnotetext{
${ }^{90}$ А. Урошевић, О Косову антропогеографске студије и други списи, 340.

${ }^{91}$ Die Gliederung der Bevölkerung des ehemaligen Jugoslawien nach Muttersprache und Konfession, 395.

${ }^{92}$ M. V. Radovanović, „Stanovništvo Prizrenskog podgora“, Glasnik muzeja Kosova i Metohije, IX, (Priština, 1964), 343.

${ }^{93}$ Deo istraživača izražava sumnju u tačnost zvaničnih podataka o brojnosti prevashodno Albanaca, računajući da je njihov broj umanjen iz političkih razloga. Videti: Ivo Banac, The National Question in Yugoslavia, Origins, History, Politics (Itaca and London Cornell University Press, 1984), 55; Muhamed Piraku, „Kulturno-prosvetni pokret Albanaca u Jugoslaviji 1919-1941“, Jugoslovenski istorijski časopis, br. 1-4, (1978), 356-370; Hairedin Hoxha, „Proces nacionalne afirmacije albanske nacionalnosti u Jugoslaviji: izabrana poglavlja“, Časopis za kritiko znanos$t i$, br. 51, 52, (1982), 237-239; Mark Krasnići, „Orahovac, antropogeografska monografija varošice“, Glasnik muzeja Kosova i Metohije, II, (Priština, 1957), 125.

${ }^{94}$ Konačni rezultati popisa stanovništva od 15 marta 1948 godine, 343-347.
} 
skog stanovništva, ${ }^{95}$ kao i tursko-rumunski dogovor iz 1935. i konvencija iz 1936. godine o iseljavanju turskog stanovništva iz Dobrudže, ${ }^{96}$ predstavljali su sredinom tridesetih godina podsticaj jugoslovenskoj vladi da se sačine planovi o potpisivanju slične konvencije sa Turskom. ${ }^{97}$ Konvenciju o iseljavanju „Turaka i stanovništva sa turskom kulturom“ Jugoslavija i Turska su potpisale 11. jula 1938, čime se predviđalo iseljenje 40.000 porodica iz 46 srezova u Vardarskoj, Moravskoj i Zetskoj banovini. ${ }^{98}$ Znajući da Turci, odnosno muslimansko stanovništvo koje se deklarisalo kao tursko, nisu predstavljali značajan demografski i politički faktor, a imajući u vidu geografiju prostora koju je trebalo da napuste iseljenici, konvencija se u osnovi odnosila na albansko stanovništvo. No, do ratifikacije konvencije sa turske strane nije došlo, pre svega zbog promenjenih međunarodnih okolnosti i početka Drugog svetskog rata.

Do novog talasa iseljavanja turskog i muslimanskog stanovništva iz Jugoslavije u Tursku doći će u izmenjenim političkim uslovima pedesetih godina 20. veka.

Broj Turaka (stanovništva turskog jezika) po srezovima 1921. i 1931.

\begin{tabular}{|l|r|r|r|r|r|r|}
\hline & \multicolumn{1}{|c|}{1921.} & & & \multicolumn{1}{c|}{1931.} & & \\
\hline Srez & Ukupno & Turci & \multicolumn{1}{c|}{$\%$} & Ukupno & \multicolumn{1}{l|}{ Turci } & \multicolumn{1}{c|}{$\%$} \\
\hline Bitolj & 55.420 & 7.095 & 12.8 & 65.164 & 5.862 & 8.9 \\
\hline Kičevo & 28.288 & 265 & 0.9 & 32.101 & 490 & 1.5 \\
\hline Kruševo & 20.618 & 21 & 0.1 & 23.570 & 42 & 0.1 \\
\hline Mariovo & 11.942 & 2.707 & 22.7 & 15.891 & 2.715 & 17.1 \\
\hline Prespa & 18.751 & 2.446 & 13.0 & 21.631 & 2.679 & 12.4 \\
\hline Prilep & 45.773 & 5.473 & 11.9 & 54.480 & 5.766 & 10.6 \\
\hline Kočani & 25.711 & 6.739 & 26.2 & 31.784 & 5.376 & 16.1 \\
\hline Maleš & 12.135 & 116 & 0.9 & 15.394 & 211 & 1.4 \\
\hline Ovče polje & 18.179 & 6.270 & 34.5 & 21.938 & 4.894 & 22.3 \\
\hline Radoviš & 16.440 & 7.056 & 42.9 & 19.461 & 7.602 & 39.0 \\
\hline Carevo Selo & 14.019 & 2.501 & 17.8 & 15.727 & 1.817 & 11.6 \\
\hline Štip & 17.863 & 6.329 & 35.4 & 19.892 & 5.864 & 29.4 \\
\hline
\end{tabular}

${ }^{95}$ Norman M. Naimark, Fires of Hatred. Ethnic Cleansing of Twentieth-Century Europe (Harvard: Harvard University Press, 2001), 42-56.

${ }^{96}$ Edvin Pezo, „Komparativna analiza jugoslovensko-turske konvencije iz 1938. i „džentlmenskog sporazuma“ iz 1953. Pregovori oko iseljavanje muslimana iz Jugoslavije u Tursku“, Tokovi istorije, br. 2, (2013), 101.

${ }^{97}$ Vladan Jovanović, „Interministerijalna konferencija Kraljevine Jugoslavije o iseljenju 'neslovenskog elementa' u Tursku (1935)“, Prilozi, br. 35, (Sarajevo, 2006), 105-124.

${ }^{98}$ Od novije literature o ovom pitanju videti: Z. Janjetović, n. d., 194-195; Vladan Jovanović, Slike jedne neuspele integracije, Kosovo, Makedonija, Srbija, Jugoslavija (Beograd: Peščanik, 2014), 109-110; Исти, Вардарска бановина, 116-117; Safet Bandžović, „Iseljenička politika balkanskih država i pitanje muslimana (1878-1941),“'Almanah, br. 29-30, (Podgorica, 2005), 228-233; E. Pezo, n. d., 108-114. 


\begin{tabular}{|c|c|c|c|c|c|c|}
\hline Žegligovo & 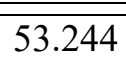 & $\overline{4.765}$ & 8.9 & $\overline{~ 66.501}$ & 3.164 & $\overline{4.7}$ \\
\hline Kratovo & 19.755 & 773 & 3.9 & 20.300 & 207 & 1.0 \\
\hline Kriva Palanka & 36.668 & 475 & 1.3 & 40.532 & 249 & 0.6 \\
\hline Gornji Debar & 14.949 & 2.020 & 13.5 & 16.296 & 1.980 & 12.1 \\
\hline Ohrid & 29.118 & 3.707 & 12.7 & 33.066 & 3.540 & 10.7 \\
\hline Struga & 25.144 & 1.779 & 7.0 & 28.055 & 1.223 & 4.4 \\
\hline Veles & 43.329 & 9.398 & 21.7 & 42.296 & 5.207 & 12.3 \\
\hline Skoplje & 91.824 & 16.938 & 18.4 & 128.052 & 16.263 & 12.7 \\
\hline Donji Polog & 61.533 & 6.915 & 11.2 & 70.983 & 7.937 & 11.2 \\
\hline Galičnik & 11.510 & 15 & 1 & 12.051 & 3 & 7 \\
\hline Gornji Polog & 28.082 & 7.177 & 25.5 & 32.666 & 7.705 & 23.6 \\
\hline Poreč & 16.054 & 440 & 2.7 & 18.740 & 47 & 0.2 \\
\hline Dojran & 8.667 & 4.367 & 50.4 & 11.713 & 5.152 & 43.9 \\
\hline Đevgelija & 11.314 & 293 & 2.6 & 15.943 & 189 & 1.2 \\
\hline Kavadarci & 25.151 & 2.915 & 11.6 & 23.919 & 593 & 2.5 \\
\hline Negotino & 14.828 & 4.127 & 27.8 & 12.876 & 2.268 & 17.6 \\
\hline Strumica & 32.475 & 5.636 & 17.5 & 38.996 & 6.380 & 16.4 \\
\hline Vučitrn & 24.308 & 1.885 & 7.8 & 32.248 & 1.731 & 5.4 \\
\hline Drenica & 19.450 & 8 & / & 21.347 & 16 & 7 \\
\hline Mitrovica & 26.379 & 3.287 & 12.5 & 30.788 & 1.307 & 4.2 \\
\hline Gnjilane & 70.030 & 2.761 & 3.9 & 91.037 & 2.212 & 2.4 \\
\hline Gračanica & 43.291 & 7.493 & 17.3 & 57.858 & 6.354 & 10.9 \\
\hline $\mathrm{Lab}$ & 26.243 & 141 & 1 & 34.797 & 18 & 7 \\
\hline Nerodimlje & 30.721 & 224 & 1 & 38.338 & 148 & 7 \\
\hline Đakovica & 32.842 & 149 & 1 & 45.378 & 33 & 7 \\
\hline Istok & 14.317 & 19 & 1 & 25.918 & 74 & 7 \\
\hline Peć & 37.074 & 1.262 & 3.4 & 44.688 & 1.667 & 3.7 \\
\hline Gora & 12.817 & 218 & 1.7 & 14.127 & 12 & 1 \\
\hline Podgora & 13.361 & 307 & 2.3 & 16.222 & 77 & 7 \\
\hline Podrima & 29.698 & 692 & 2.3 & 36.191 & 900 & 2.5 \\
\hline Has & 7.377 & 1 & 1 & 1 & 1 & 7 \\
\hline Šar-planina & 33.528 & 9.463 & 25.2 & 46.154 & 9.145 & 19.8 \\
\hline Preševo & 37.517 & 800 & 2.1 & 44.905 & 966 & 2.2 \\
\hline
\end{tabular}

Izvor: Definitivni rezultati popisa stanovništva 1921 godine (Sarajevo, 1932); Die Gliederung der Bevölkerung des ehemaligen Jugoslawien nach Muttersprache und Konfession nach den unveröffentlichen Angaben der Zählung ven 1931 (Wien, 1943). 


\section{REFERENCE}

- Albansko stanovništvo u Socijalističkoj Republici Makedoniji. Beograd: Književne novine, 1988.

- Banac, Ivo. The National Question in Yugoslavia, Origins, History, Politics. Itaca and London Cornell University Press, 1984.

- Bandžović, Safet. „Iseljenička politika balkanskih država i pitanje muslimana (1878-1941)“. Almanah, br. 29-30, (Podgorica, 2005), 187-234.

- Čalić, Mari-Žanin. Istorija Jugoslavije u 20. veku. Beograd: Clio, 2013.

- Čučković, Manojlo R. „Varošica Sveti Nikole na Ovčem Polju“. Glasnik skopskog naučnog društva, knj. XV-XVI, (Skoplje, 1936), 281-289.

- Definitivni rezultati popisa stanovništva 1921 godine. Sarajevo: Opšta državna statistika, 1932.

- Definitivni rezultati popisa stanovništva od 31 marta 1931 godine, knjiga I, Prisutno stanovništvo, broj kuća i domaćinstava. Beograd: Državna statistika, 1937.

- Die Gliederung der Bevölkerung des ehemaligen Jugoslawien nach Muttersprache und Konfession nach den unveröffentlichen Angaben der Zählung ven 1931. Wien, 1943.

- Filipović, Milenko. Severna veleška sela. Beograd: Srpska kraljevska akademija, 1935.

- Filipović, S. Milenko. „Etničke prilike u Južnoj Srbiji“. U: Spomenica dvadesetpetogodišnjice oslobođenja Južne Srbije 1912-1937. Urednik Aleksa Jovanović, 387-497. Skoplje: Odbor za proslavu dvadesetpetogodišnjice oslobođenja Južne Srbije, 1937.

- Gadzhanov, Dimitar G. „Mjusjumanskoto naselenie v novoosvobodenite zemi““. V: Nauchna ekspedicija Makedonija i Pomoravieto, 1916 g. S"st. Pet"r Hr. Petrov, 231-279. Sofija: Universitetsko izdatelstvo „Sv. Kliment Ohridski“ 1993.

- Hadži Vasiljević, Jovan. „Muslimani naše krvi u Južnoj Srbiji“. Brastvo, knj. 32, (Beograd, 1925), 21-95.

- Hadzhidinev, Kiril. Dojran. Sofija: Izdatelstvo na nacionalnija syvet na otechestvenija front, 1960.

- Hoxha, Hairedin. „Proces nacionalne afirmacije albanske nacionalnosti u Jugoslaviji: izabrana poglavlja“. Časopis za kritiko znanosti, br. 51, 52, (Ljubljana, 1982), 237-248.

- Ishirkov, Anastas. „Pytuvane v Makedonija i Pomoravija“. V: Nauchna ekspedicija Makedonija i Pomoravieto, 1916 g. S"st. Pet"r Hr. Petrov, 106117. Sofija: Universitetsko izdatelstvo „Sv. Kliment Ohridski“, 1993.

- Ivanov", Jordan". B"lgarite v" Makedonija. Sofija: Bylgarskata akademija na naukite, 1915.

- Jagodić, Miloš. Srpsko-albanski odnosi u Kosovskom vilajetu. Beograd: Zavod za udžbenike, 2009.

- Jagodić, Miloš. Novi krajevi Srbije (1912-1915). Beograd: Filozofski fakultet, Univerzitet u Beogradu, 2013. 
- Jagodić, Miloš. „Procena demografskih gubitaka Srba u periodu 1910-1921“. Srpske studije, knj. 6, (Beograd, 2015), 11-65.

- Janjetović, Zoran. Deca careva pastorčad kraljeva. Nacionalne manjine u Jugoslaviji 1918-1941. Beograd: INIS, 2005.

- Jovanović, Vladan. „Interministerijalna konferencija Kraljevine Jugoslavije o iseljenju 'neslovenskog elementa' u Tursku (1935)“. Prilozi, br. 35, (Sarajevo, 2006), 105-124.

- Jovanović, Vladan. „Iseljavanje muslimana iz Vardarske banovine - između stihije i državne akcije“. U: Pisati istoriju Jugoslavije: Viđenje srpskog faktora, Zbornik radova. Urednik Mile Bjelajac, 79-99. Beograd: INIS, 2007.

- Jovanović, Vladan. Vardarska banovina 1929-1941. Beograd: INIS, 2011.

- Jovanović, Vladan. Slike jedne neuspele integracije, Kosovo, Makedonija, Srbija, Jugoslavija. Beograd: Peščanik, 2014.

- Kočović, Bogoljub. Etnički i demografski razvoj u Jugoslaviji od 1921. do 1991. godine (po svim zvaničnim a u nekim slučajevima i korigovanim popisima), sveska I. Paris: Bibliothėque Dialogue, 1998.

- Kostić, Mita. „Iz istorije kolonizacije Južne Srbije krajem prošlog veka“. Glasnik skopskog naučnog društva, knj. 12, (Skoplje, 1933), 235-241.

- Krasnići, Mark. „Orahovac, antropogeografska monografija varošice“. Glasnik Muzeja Kosova i Metohije, II, (Priština, 1957), 87-143.

- K"nchov, Vasil. Izbrani proizvedenija, tom II. Sofija: Izdatelstvo nauka i iskustvo, 1970.

- K"nchov, Vasil. Makedonija etnografija i statistika. Sofija: Akad. izd. prof. Marin Drinov, 1996, (2. reprint izdaњe).

- Makkarti, Dzhastin. Sm"rt i izgnanie Etnichesko prochistvane na osmanskite mjuslimani 1821-1922. Sofija: Universitetsko izdatelstvo „Sv. Kliment Ohridski, 2010.

- Naimark, Norman M. Fires of Hatred. Ethnic Cleansing of Twentieth-Century Europe. Harvard: Harvard University Press, 2001.

- Petrović, Rudolf. Polog antropogeografski prikaz. Zagreb: Preporod, 1942.

- Pezo, Edvin. „Komparativna analiza jugoslovensko-turske konvencije iz 1938. i „džentlmenskog sporazuma“ iz 1953. Pregovori oko iseljavanje muslimana iz Jugoslavije u Tursku“. Tokovi istorije, br. 2 (2013), 97-120.

- Piraku, Muhamed. „Kulturno-prosvetni pokret Albanaca u Jugoslaviji 19191941“. Jugoslovenski istorijski časopis, br. 1-4, (1978), 356-370.

- Poranešnite balkanski vojni (1912-1913), izveštaj na Karnegievata balkanska komisija. Skopje: Kultura, 2000.

- Prifti, Kristaq. Popullsia e Kosovës 1831-1912. Tiranë: Akademia e Shkencave Shqipërisë, 2014.

- Radovanović, M. V. „Stanovništvo Prizrenskog podgora“. Glasnik Muzeja Kosova i Metohije, IX, (Priština, 1964).

- Rusić, Branislav. Župa Debarska. Skoplje: Filozofski fakultet, 1957. 
- Salname na Vilaetot Kosovo, prevod od Osmansko - turski jazik. Prevod i komentari Dragi Ǵorgiev i Ahmed Šerif. Skopje: Sojuz na Turskite Nevladini Organizacii vo Makedonija, 2012.

- Srpski izvori za istorijata na makedonskiot narod 1912-1914. Izbor, redakcija i komentari Gligor Todorovski. Skopje: Institut za nacionalnu istoriju, 1979.

- Trifunoski, Jovan F. „Ovčepoljska kotlina“. Zbornik za narodni život i običaje Južnih Slavena, knj. 42, (1964), 585-762.

- Stanovništvo predratne Jugoslavije po veroispovesti i maternjem jeziku po popisu od 31.III.1931 godine - pregled po srezovima, Državni statistički ured, serija II, sveska 3. Beograd: Državna statistika, 1945.

- Trifunoski, Jovan F. Kočanska kotlina, seoska naselja i stanovništvo. Skopje: b. i., 1970.

- Trifunoski, Jovan F. Polog (antropogeografska proučavanja). Beograd: Srpska akademija nauka i umetnosti, 1976.

- Trifunoski, Jovan F. „Oblast Babune i Topolke“. Zbornik za narodni život $i$ običaje Južnih Slavena, knj. 47, (Zagreb, 1977), 127-290.

- Trifunoski Jovan F. „Savremeni etnički procesi u Skoplju“. Etnološki pregled, br. 13, (1975), 123-130.

- Trifunoski, Jovan F. Bitoljsko-prilepska kotlina, antropogeografska proučavanja. Beograd: Srpska akademija nauka i umetnosti, 1998.

- Urošević, Atanasije. „Vučitrn“. Glasnik skopskog naučnog društva, knj. XIX, (1938), 215-230.

- Urošević, Atanasije. Gnjilane. Beograd: b. i., 1931.

- Urošević, Atanasije. Ohrid geografska monografija. Skopje: Filozofski fakultet na Univerzitetot, 1957.

- Urošević, Atanasije. O Kosovu antropogeografske studije i drugi spisi. Priština, Gnjilane: Institut za srpsku kulturu, 2001.

- Vujičić, Ant. Mil. Rečnik mesta u Oslobođenoj oblasti Stare Srbije. Po službenim podatcima. Beograd: Državna štamparija Kraljevine Srbije, 1914. 
BORČE ILIEVSKI, PhD, Associate Professor

Faculty of Philosophy, University „Sv. Kirilo i Metodije“

Skopje, Republic of Macedonia

borce@fzf.ukim.edu.mk

\section{THE TURKS IN THE KINGDOM OF SCS/YUGOSLAVIA A DEMOGRAPHIC ANALYSIS BASED ON THE CENSUSES OF 1921 AND 1931}

\section{Summary}

The censuses of 1921 and 1931 show a steady Turkish population decline in the Kingdom of Yugoslavia. Turks populated the areas that until 1912 were under Ottoman rule and the Balkan Wars prompted a process of their migration to Asia Minor. Due to this migration, while in 1912 there was about 195,000 Turks in Vardar Macedonia, in the census of 1931 the number of residents whose native language was Turkish (by the statistical methodology of the time) totaled 105,407. The statistics of 1931 reveal that less than two decades of the Balkan Wars, Turks were no longer a majority in any of the administrative areas in which they constituted a sizable part or the majority of the population until 1912. Part of the urban Muslim population (Albanian and South Slavic) reported their mother tongue was Turkish in both censuses taken between the two World Wars, just as they did before the Balkan Wars because of the Turkish influence, culture, deeply rooted Islam and their coexistence with the Turks. This was characteristic of the cities in the northern and western parts of Vardar Macedonia and of several urban centers in the region of Kosovo and Metohija and was also the reason why certain scholars raised doubts about the accuracy of the official statistics.

Most of the Turks who lost hope in the reinstitution of the Ottoman rule and who did not migrate to Turkey, were loyal to the authorities of the Kingdom, which frequently relied on the most distinguished individuals of their community as representatives of a significant Muslim minority. That, however, was not the case with the Albanians.

KEYWORDS: Turks, Kingdom of Yugoslavia, Migrations, Demographic changes, Censuses of population 